\title{
mGluR1/TRPC3-mediated Synaptic Transmission and Calcium Signaling in Mammalian Central Neurons
}

\author{
Jana Hartmann, Horst A. Henning, and Arthur Konnerth \\ Institute of Neuroscience and Center for Integrated Protein Science, Technical University of Munich, \\ Munich, Germany \\ Correspondence: jana.hartmann@Irz.tum.de
}

\begin{abstract}
Metabotropic glutamate receptors type 1 (mGluR1s) are required for a normal function of the mammalian brain. They are particularly important for synaptic signaling and plasticity in the cerebellum. Unlike ionotropic glutamate receptors that mediate rapid synaptic transmission, mGluR1s produce in cerebellar Purkinje cells a complex postsynaptic response consisting of two distinct signal components, namely a local dendritic calcium signal and a slow excitatory postsynaptic potential. The basic mechanisms underlying these synaptic responses were clarified in recent years. First, the work of several groups established that the dendritic calcium signal results from $I P_{3}$ receptor-mediated calcium release from internal stores. Second, it was recently found that mGluR1-mediated slow excitatory postsynaptic potentials are mediated by the transient receptor potential channel TRPC3. This surprising finding established TRPC3 as a novel postsynaptic channel for glutamatergic synaptic transmission.
\end{abstract}

\begin{abstract}
Clutamate is the predominant neurotrans$\checkmark$ mitter used by excitatory synapses in the mammalian brain (Hayashi 1952; Curtis et al. 1959). At postsynaptic sites, glutamate binds to two different classes of receptors, namely the ionotropic glutamate receptors (iGluRs) and the metabotropic glutamate receptors (mGluRs) (Sladeczek et al. 1985; Nicoletti et al. 1986; Sugiyama et al. 1987). The iGluRs represent ligand-gated nonselective cation channels that underlie excitatory postsynaptic currents (EPSCs). Based on their subunit composition, gating, and permeability properties, they are subdivided into three groups named after specific
\end{abstract}

agonists: AMPA- ( $\alpha$-amino-3-hydroxy-5-methyl-4-isoxazolepropionic acid), NMDA receptors ( $N$-methyl $D$-aspartate receptors) and kainate receptors (Alexander et al. 2009). The other class of glutamate receptors, the mGluRs, consists of receptors that are coupled to $G$ proteins and act through distinct downstream signaling cascades. They are structurally different from iGluRs and characterized by the presence of seven transmembrane domains (Houamed et al. 1991; Masu et al. 1991). The mGluRs exist as homodimers that do not by themselves form an ionpermeable pore in the membrane (Ozawa et al. 1998). To date, eight different genes (and more

Editors: Martin D. Bootman, Michael J. Berridge, James W. Putney, and H. Llewelyn Roderick Additional Perspectives on Calcium Signaling available at www.cshperspectives.org

Copyright (C) 2011 Cold Spring Harbor Laboratory Press; all rights reserved; doi: 10.1101/cshperspect.a006726

Cite this article as Cold Spring Harb Perspect Biol 2011;3:a006726 
Hartmann et al.

splice variants) encoding mGluRs have been identified and form the mGluR1 through mGluR8 subtypes (Alexander et al. 2009). Based on the amino acid sequence homology, downstream signal transduction pathways, and pharmacological properties, each of the subtypes was assigned to one of three groups. Group I receptors consist of mGluR1 and mGluR5 that positively couple to the phospholipase C (PLC). The receptors mGluR2 and mGluR3 constitute group II, whereas the remaining mGluRs, namely mGluR4, mGluR6, mGluR7, and mGluR8, belong to group III. Both groups II and III inhibit the adenylyl cyclase and thereby reduce the concentration of cAMP in the cytosol.

Of all different subtypes, mGluR1 is the most abundantly expressed mGluR in the mammalian central nervous system. In the brain, mGluR1 is highly expressed in the olfactory bulb, dentate gyrus, and cerebellum (Lein et al. 2007). The highest expression level of mGluR1 in the brain is found in Purkinje cells, the principal neurons of the cerebellar cortex (Shigemoto et al. 1992; Lein et al. 2007). Together with the AMPA receptors, mGluR1s are part of the excitatory synapses formed between parallel fibers and Purkinje cells (Fig. 1A). Each Purkinje cell is innervated by $100,000-$ 200,000 parallel fibers (Ito 2006) that are axons of the cerebellar granule cells, the most abundant type of neuron in the brain. A second type of excitatory input to Purkinje cells is represented by the climbing fibers that originate in the inferior olive in the brain stem (Ito 2006). The two excitatory synaptic inputs to Purkinje cells are important determinants for the main functions of the cerebellum, including the realtime control of movement precision, errorcorrection, and control of posture as well as the procedural learning of complex movement sequences and conditioned responses.

It is expected that mGluR1 is involved in many of these cerebellar functions. This view is supported by the observation that mGluR1deficient knockout mice show severe impairments in motor coordination. In particular, the gait of these mice is strongly affected as well as their ability for motor learning and general coordination (Aiba et al. 1994). The phenotype of the general mGluR1-knockout mice is rescued by the insertion of the gene encoding mGluR1 exclusively into cerebellar Purkinje cells (Ichise et al. 2000) and blockade of mGluR1 expression only in Purkinje cells of adult mice leads to impaired motor coordination (Nakao et al. 2007). These findings established mGluR1 in Purkinje cell as synaptic receptors that are indispensable for a normal cerebellar function.

Synaptic transmission involving mGluR1s is found at both parallel fiber-Purkinje cell synapses (Batchelor and Garthwaite 1993; Batchelor et al. 1994) as well as at climbing fiber-Purkinje cell synapses (Dzubay and Otis 2002). Most of our knowledge on the mGluR1 was gained from the analysis of the parallel fiber synapses. The parallel fiber synapse is quite unique in the central nervous system regarding its endowment with neurotransmitter receptors. In contrast to most other glutamatergic synapses in the mammalian brain, it lacks functional NMDA receptors (Shin and Linden 2005). The entire synaptic transmission at these synapses relies on AMPA receptors and on mGluR1 (Takechi et al. 1998). Although AMPA receptors are effectively activated even with single shock stimuli (Konnerth et al. 1990; Llano et al. 1991b), activation of mGluRs requires repetitive stimulation (Batchelor and Garthwaite 1993; Batchelor et al. 1994; Batchelor and Garthwaite 1997; Takechi et al. 1998). A possible explanation for the need of repetitive stimulation may relate to the observation that mGluR1s are found mostly at the periphery of the subsynaptic region (Nusser et al. 1994). At these sites outside the synaptic cleft, glutamate levels that are sufficiently high for receptor activation may be reached only with repetitive stimulation.

At parallel fiber-Purkinje cell synapses, repetitive stimulation produces an initial AMPA receptor postsynaptic signal component, followed by a more prolonged mGluR1 component (Fig. 1). Figure 1B shows a current clamp recording of this response consisting of an early burst of action potentials, followed by a prolonged depolarization known as a "slow excitatory postsynaptic potential" (slow EPSP) 
A

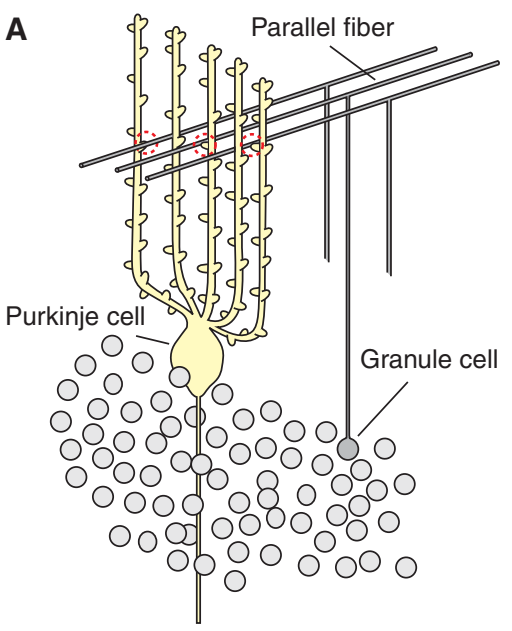

B

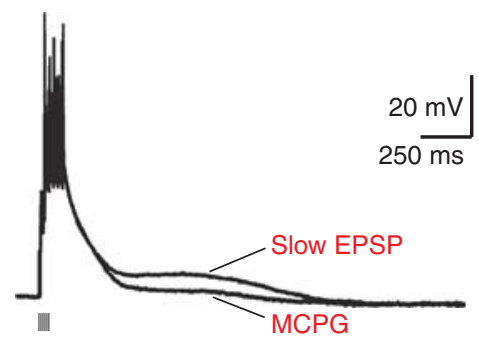

Synaptic Transmission Mediated by mGluR1 and TRPC3

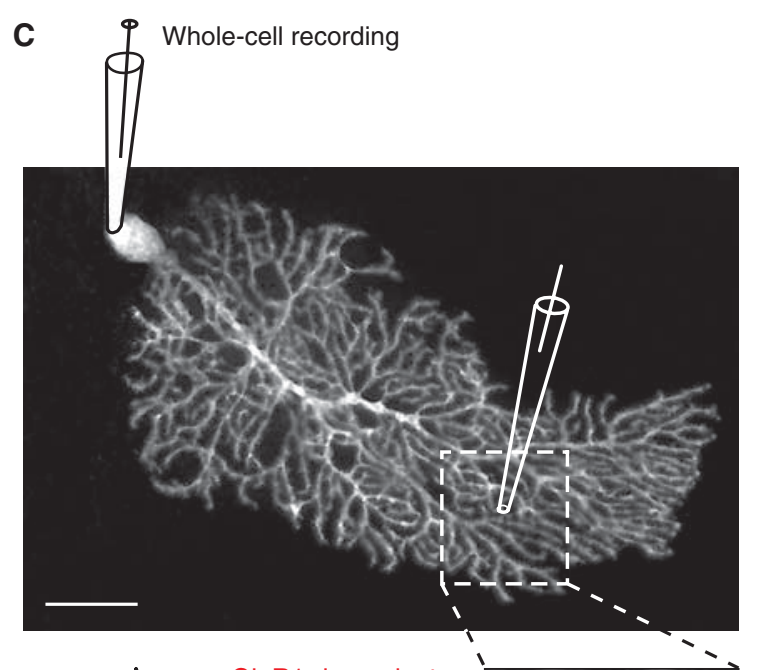

D

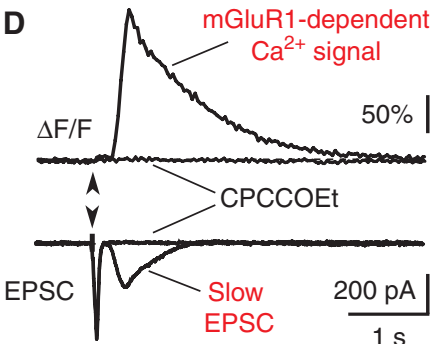

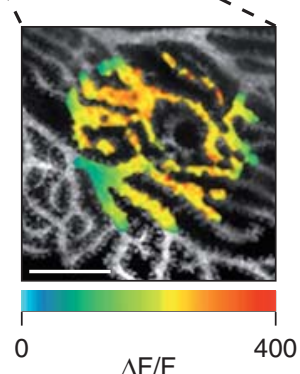

Figure 1. Parallel fiber-evoked mGluR1-dependent signals. (A) Diagram showing the parallel fiber synaptic input to Purkinje cell dendrites. $(B)$ Microelectrode recording of glutamatergic postsynaptic potentials from a Purkinje cell in an acute slice of adult rat cerebellum. Short trains of stimuli to the parallel fibers (5-6 at $50 \mathrm{~Hz}$ ) caused summation of the early AMPA receptor-dependent EPSPs (leading to spike firing) and a slow, delayed, depolarizing potential (slow EPSP), which was reversibly inhibited by antagonist of mGluRs $(+)-M C P G(1 \mathrm{mM})$. (C) Confocal image of a patch-clamped Purkinje cell in a cerebellar slice of an adult mouse. The patch-clamp pipette and the glass capillary used for electrical stimulation of parallel fibers are depicted schematically. The site of stimulation is shown at higher magnification in $D$. (D) Left: Parallel fiber-evoked (five pulses at $200 \mathrm{~Hz}$, in $10 \mathrm{mM} \mathrm{CNQX)} \mathrm{synaptic} \mathrm{responses} \mathrm{consisting} \mathrm{of} \mathrm{a} \mathrm{dendritic} \mathrm{mGluR1-dependent} \mathrm{Ca}^{2+}$ transient $(\Delta \mathrm{F} / \mathrm{F}$, top $)$ and an early rapid and a slow excitatory postsynaptic current (EPSC, bottom). Block of the mGluR1-dependent components by the group I-specific mGluR-antagonist CPCCOEt $(200 \mu \mathrm{M})$ is shown as indicated. Right: Pseudocolor image of the synaptic $\mathrm{Ca}^{2+}$ signal. ( $B$, Reprinted with modifications, with permission, from Batchelor and Gaithwaite 1997 [Nature Publishing Group].)

(Batchelor and Garthwaite 1993; Batchelor et al. 1994; Batchelor and Garthwaite 1997). Voltageclamp recordings allow a clear separation of the initial rapid, AMPA receptor mediated excitatory postsynaptic current (EPSC) and the mGluR1-mediated slow EPSC (Fig. 1D) (Takechi et al. 1998; Hartmann et al. 2008). In addition of inducing the slow EPSPs, mGluR1s mediate a large and highly localized dendritic calcium transient in cerebellar Purkinje cells
(Fig. 1D) (Llano et al. 1991a; Finch and Augustine 1998; Takechi et al. 1998).

\section{mGluR1-DEPENDENT POSTSYNAPTIC $\mathrm{Ca}^{2+}$ RELEASE FROM INTERNAL STORES}

The mGluR1-mediated synaptic $\mathrm{Ca}^{2+}$ transients constitute a distinct class of postsynaptic response because they may occur independently from changes in membrane potential (Takechi 
Hartmann et al.

et al. 1998). The generation of these $\mathrm{Ca}^{2+}$ transients is the result of a cascade of signaling events. During the initial step, binding of glutamate to the mGluR1 activates the phospholipase C (PLC). This is followed by inositoltrisphosphate $\left(\mathrm{IP}_{3}\right)$ production and accumulation in the cytosol. $\mathrm{IP}_{3}$ binds to its own receptor channels that are located in the endoplasmic reticulum (ER) membrane and are permeable for $\mathrm{Ca}^{2+}$ (Verkhratsky 2005). At parallel fiber-Purkinje cell synapses, the release of $\mathrm{Ca}^{2+}$ from ER stores forms a characteristic local signaling response (Finch and Augustine 1998; Takechi et al. 1998). An important feature of the mGluR1-dependent $\mathrm{Ca}^{2+}$ signal is its spatial restriction ranging from dendritic regions (Fig. 1C) to small dendritic terminal branchlets or even to single spines (Fig. 2). Focal synaptic stimulation involving the activation of just a few neighboring parallel fibers causes mGluR1dependendent $\mathrm{Ca}^{2+}$ signals that occur at tiny spino-dendritic regions (Fig. 2, spine 2-dendrite 2) or in individual spines (Fig. 2, spine 1) (Fig. 2B) (Takechi et al. 1998). However, there is evidence that nominally similar parallel fiber synaptic inputs may cause variable postsynaptic $\mathrm{Ca}^{2+}$ transients, depending apparently on the dendritic location (Hartmann et al. 2004). Possibly, this variability may relate to a heterogeneity of the organization of the smooth ER network in the Purkinje cell dendrites and spines (Harris and Stevens 1988; Martone et al. 1993; Terasaki et al. 1994). Alternatively, there may be an uneven distribution of $\mathrm{IP}_{3}$ receptors, ryanodine receptors (RyRs), $\mathrm{Ca}^{2+}$ ATPases and luminal $\mathrm{Ca}^{2+}$-binding proteins, like calsequestrin, calnexin and calreticulin, in the dendritic tree of Purkinje cells (Villa et al.

$\mathbf{A}$

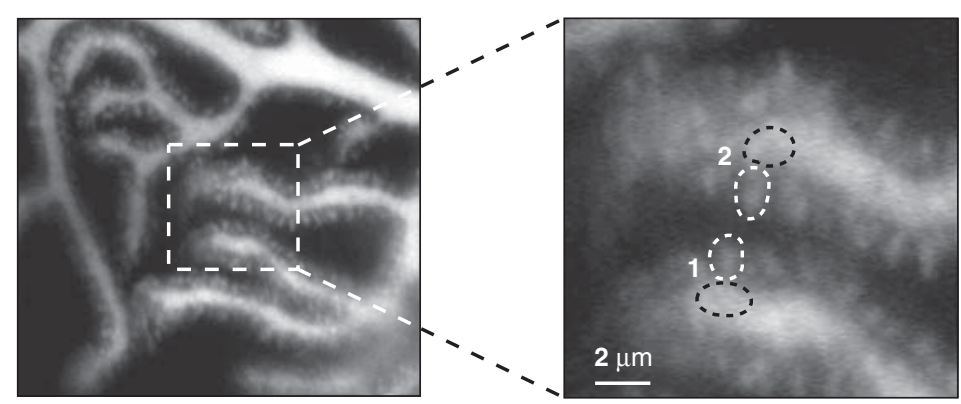

B Control

$M C P G$
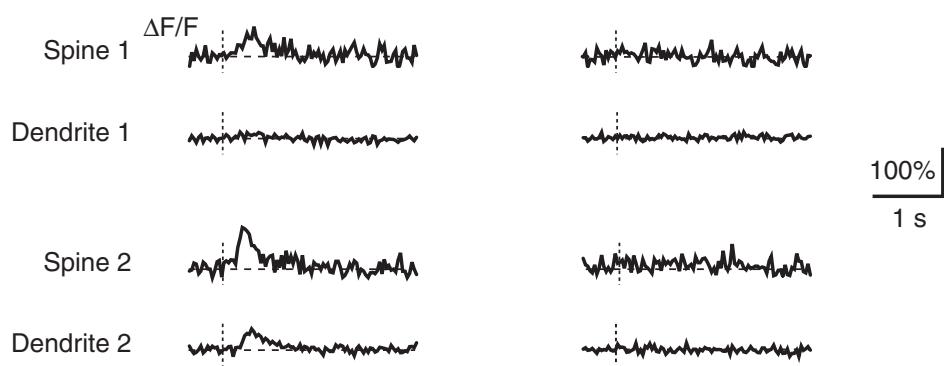

Figure 2. Identification of synaptic $\mathrm{Ca}^{2+}$-release signals in spines and dendritic microdomains (Takechi et al. 1998). (A) Images of spiny dendrites of a Purkinje cell, indicating the sites of fluorescence measurements. (B) Fluorescence measurements taken from the dendrites shown in A. In spine 1, the synaptic $\mathrm{Ca}^{2+}$ transient was restricted to an individual spine. Note the complete absence of any $\mathrm{Ca}^{2+}$ signal in the immediate dendritic vicinity. A large synaptic $\mathrm{Ca}^{2+}$ transient was detected in spine 2 and a smaller signal occurred in the subspine region. MCPG $(1 \mathrm{mM})$ completely blocked all synaptic $\mathrm{Ca}^{2+}$ transients. 
1991; Takei et al. 1992; Villa et al. 1992; Nori et al. 1993).

A more detailed dissection of the intracellular signaling cascade shows that mGluR1s couple to their downstream effectors through members of the $\mathrm{G}_{\mathrm{q}}$ protein subclass of heterotrimeric G proteins (Masu et al. 1991). Only two members of this $G$ protein family, $G \alpha_{q}$ and $\mathrm{G} \alpha_{11}$, are expressed in the brain (Nakamura et al. 1991; Wilkie et al. 1991). Both are present also in Purkinje cells (Tanaka et al. 2000) and it has been shown that the $\mathrm{G} \alpha_{\mathrm{q}} / \mathrm{G} \alpha_{11}$ immunoreactivity colocalizes with mGluR1 in Purkinje cell spines (Tanaka et al. 2000). However, measurements of postsynaptic $\mathrm{Ca}^{2+}$ signals in Purkinje cells in mice deficient for either $\mathrm{G} \alpha_{\mathrm{q}}$ or $\mathrm{G} \alpha_{11}$ revealed that only $\mathrm{G} \alpha_{\mathrm{q}}$, but not $\mathrm{G} \alpha_{11}$, is required for mGluR-mediated $\mathrm{Ca}^{2+}$ transients (Hartmann et al. 2004).

$\mathrm{G}_{\mathrm{q}}$ proteins activate the PLC $\beta$ of which four subtypes (PLC $\beta 1-4)$ have been identified (Blank et al. 1991; Berstein et al. 1992; Rebecchi and Pentyala 2000). Purkinje cells express all subtypes with the exception of the PLC 32 (Tanaka and Kondo 1994; Roustan et al. 1995; Watanabe et al. 1998; Lein et al. 2007). PLC $\beta 1$ has the lowest and PLC $\beta 4$ the highest expression level in Purkinje cells (Lein et al. 2007). PLC 33 prevails in the caudal cerebellum (Hirono et al. 2001), whereas PLCß4 is reciprocally expressed in the rostral lobuli of the cerebellum (Kano et al. 1998). PLC $\beta 1$ is present primarily in the somata of Purkinje cells and is, therefore, unlikely to play a major role in synaptic transmission at parallel fiber synapses that are all located in the spiny dendrites (Kano et al. 1998).

Of all three $\mathrm{IP}_{3}$ receptor subtypes, $\mathrm{IP}_{3} \mathrm{R} 1$ is expressed in Purkinje cells with extraordinary high density (Sharp et al. 1999; Lein et al. 2007). $\mathrm{IP}_{3} \mathrm{R} 2$ is present in low amounts, whereas $\mathrm{IP}_{3} \mathrm{R} 3$ is not found in Purkinje cells (Lein et al. 2007). Most remarkably, the signaling properties of the $\mathrm{IP}_{3} \mathrm{R} 1$ in its native environment in the Purkinje cell cytosol differ largely from those detected in isolated preparations or other cell types (Khodakhah and Ogden 1993; Fujiwara et al. 2001). With an EC50 of $25.8 \mu \mathrm{M}$ (Fujiwara et al. 2001) its sensitivity for $\mathrm{IP}_{3}$ is exceptionally low, indicating that
10- to 20-fold higher concentrations of $\mathrm{IP}_{3}$ are required to evoke $\mathrm{Ca}^{2+}$-release from stores as compared with astrocytes, hepatocytes, exocrine cells and vascular endothelium (Khodakhah and Ogden 1993). Intriguingly, $\mathrm{IP}_{3} \mathrm{Rs}$ isolated from Purkinje cells have a sensitivity for $\mathrm{IP}_{3}$ that is similar to that found in other cell types (Fujiwara et al. 2001). In general, the $\mathrm{IP}_{3} \mathrm{R}$ forms a "macro" signal complex in which it operates as an integrator and regulator for signaling cascades. The most important regulators of the $\mathrm{IP}_{3} \mathrm{R}$ are $\mathrm{Ca}^{2+}$ ions, calmodulin, the immunophilin FKBP12, ATP, and protein kinases (reviewed in Patterson et al. [2004]; Mikoshiba [2007]). Notably, calmodulin specifically inhibits $\mathrm{IP}_{3}$-binding to $\mathrm{IP}_{3} \mathrm{R} 1$ receptors and $\mathrm{IP}_{3}$-evoked $\mathrm{Ca}^{2+}$ mobilization in a $\mathrm{Ca}^{2+}$ independent manner (Patel et al. 1997; Cardy and Taylor 1998). Because of its high expression in Purkinje cells, calmodulin may be responsible for the low affinity of the $\mathrm{IP}_{3} \mathrm{R} 1$ for $\mathrm{IP}_{3}$ in the Purkinje cell cytosol. A $\mathrm{Ca}^{2+}$-independent binding to the $\mathrm{IP}_{3} \mathrm{R} 1$ has been reported also for $\mathrm{CaBP} 1$, a member of the neuronal $\mathrm{Ca}^{2+}$ sensor family of $\mathrm{Ca}^{2+}$ binding proteins. The interaction of CaBP1 with the amino terminus of the $\mathrm{IP}_{3} \mathrm{R} 1$ results in a weakened $\mathrm{IP}_{3}$ binding to the receptor, similarly to the effect of calmodulin (Kasri et al. 2004). However, because of its very low expression in Purkinje cells (Lein et al. 2007), CaBP1 does not seem to be a major cause for the specific features of $\mathrm{IP}_{3} \mathrm{R}$-dependent $\mathrm{Ca}^{2+}$-signaling in this cell type. Instead, it is assumed that, in addition to calmodulin, in Purkinje cells the $\mathrm{IP}_{3} \mathrm{R} 1$ is specifically regulated by proteins like the $\mathrm{IP}_{3}$ inhibitor IRI (Watras et al. 2000) or the carbonic anhydrase-related protein CARP (Nogradi et al. 1997). Interestingly, the expression of CARP is restricted to Purkinje cells (Nogradi et al. 1997) in which it reduces the affinity of $\mathrm{IP}_{3} \mathrm{R} 1$ for $\mathrm{IP}_{3}$ by binding to the modulatory domain of $\mathrm{IP}_{3} \mathrm{R} 1$ (Hirota et al. 2003). On the behavioral level, the relevance of the carbonic anhydrase activity for $\mathrm{IP}_{3} \mathrm{R}$-dependent signaling in Purkinje cells is emphasized by the fact that a mutation in the carbonic anhydrase related protein 8 (Car8) is associated with a pronounced ataxic gait (Jiao et al. 2005), whereas on the ultrastructural level, 
Hartmann et al.

Purkinje cells show various synaptic anomalies (Hirasawa et al. 2007). Even though the affinity of the $\mathrm{IP}_{3} \mathrm{R} 1$ for its agonist in Purkinje cells is low, the magnitude of $\mathrm{Ca}^{2+}$ release signal from the ER $\mathrm{Ca}^{2+}$ store is much larger than in other cell types (Khodakhah and Ogden 1993; Ogden and Capiod 1997). Furthermore, in comparison to cells in other tissues, in Purkinje cells the kinetics of activation and $\mathrm{Ca}^{2+}$ dependent inactivation (Bezprozvanny et al. 1991) of the $\mathrm{IP}_{3} \mathrm{R} 1$ are particularly fast (Khodakhah and Ogden 1995; Ogden and Capiod 1997). For a cytosolic $\mathrm{IP}_{3}$ concentration of $38 \mu \mathrm{M}$ following photorelease of "caged" $\mathrm{IP}_{3}$, the efflux of $\mathrm{Ca}^{2+}$ ions from the ER was estimated to be $\approx 1 \mu \mathrm{M} / \mathrm{ms}$ in Purkinje cells and only $\approx 0.03 \mu \mathrm{M} / \mathrm{ms}$ in cells from peripheral tissues (Khodakhah and Ogden 1993). Together, these observations suggest that $\mathrm{IP}_{3}$-dependent $\mathrm{Ca}^{2+}$-release in Purkinje cells is particularly fine-tuned for signaling on the time scale of synaptic transmission in the millisecond range, which takes place in a localized space adjacent to the site of synaptic inputs (Takechi et al. 1998).

An increasing amount of evidence indicates that the mGluR1-mediated synaptic $\mathrm{Ca}^{2+}$ release signal from stores plays an important role in activity dependent synaptic plasticity. Thus, parallel fiber synapse-mediated $\mathrm{IP}_{3} \mathrm{R} 1$ dependent $\mathrm{Ca}^{2+}$ transients are required for the induction of long-term depression (LTD) at parallel fiber-Purkinje cell synapses (Kasono and Hirano 1995; Khodakhah and Armstrong 1997; Finch and Augustine 1998; Inoue et al. 1998; Daniel et al. 1999). LTD, the presumed cellular basis of motor learning in the cerebellum (Ito 2000) requires the conjunctive stimulation of parallel and climbing fiber inputs (Gao et al. 2003). During LTD induction, parallel fiber firing activates mGluR1-dependent pathways that include $\mathrm{IP}_{3} \mathrm{R} 1$-mediated release of $\mathrm{Ca}^{2+}$ ions from $\mathrm{ER} \mathrm{Ca}^{2+}$ stores, whereas climbing fiber activity strongly depolarizes the Purkinje cells and induces influx of $\mathrm{Ca}^{2+}$ ions through voltage-gated $\mathrm{Ca}^{2+}$ channels (Knöpfel et al. 1991). The increased cytosolic concentrations of $\mathrm{Ca}^{2+}$ and $\mathrm{IP}_{3}$ are, thus, the result of the concerted parallel and climbing fiber activity.
Because of their sensitivity to both $\mathrm{IP}_{3}$ and $\mathrm{Ca}^{2+}$ (Bezprozvanny et al. 1991), $\mathrm{IP}_{3} \mathrm{R} 1 \mathrm{~s}$ act as coincidence detectors for the two excitatory inputs onto Purkinje cells and mediate an amplification of the postsynaptic $\mathrm{Ca}^{2+}$ release signal. This facilitates the induction of LTD (Wang et al. 2000; Doi et al. 2005). Experimental evidence indicates that $\mathrm{IP}_{3} \mathrm{R} 1$-mediated $\mathrm{Ca}^{2+}$ release in the spines themselves is of outstanding importance for the induction of LTD. Thus, LTD was absent in a myosin-Va mutant mouse line, in which the ER does not extend into dendritic spines (Miyata et al. 2000). Furthermore, $\mathrm{IP}_{3} \mathrm{R}$-dependent $\mathrm{Ca}^{2+}$ release in single spines elicited by sparse parallel fiber stimulation is able to induce LTD specifically at the activated input (Wang et al. 2000).

\section{MECHANISMS UNDERLYING mGluR1-DEPENDENT SYNAPTIC DEPOLARIZATION}

As mentioned above, repetitive stimulation of parallel fiber inputs evokes a slow EPSC that is sensitive to mGluR-specific antagonists (Batchelor and Garthwaite 1993; Batchelor et al. 1994). Remarkably, the frequencies that are most effective in brain slices (Batchelor and Garthwaite 1997) resemble those that are encountered with the stimulation of parallel (Isope et al. 2004) or mossy fibers in vivo (Chadderton et al. 2004). The slow EPSC is characterized by a characteristic time course: it starts with a latency of $100-200 \mathrm{~ms}$ after the stimulation of afferent parallel fibers and lasts for about 1 second (Fig. 1D)(Batchelor et al. 1994). The long search for the mechanisms underlying the slow EPSC involved pharmacological experiments that indicated that the mGluR1mediated slow EPSC is not mediated by hyperpolarization-activated cation channels, purinergic receptors (Canepari et al. 2001), $\mathrm{Na}^{+} / \mathrm{Ca}^{2+}$-exchangers (Hirono et al. 1998) or voltage-gated $\mathrm{Ca}^{2+}$ channels (Tempia et al. 2001). Instead, the ionic properties of the slow EPSCs are reminiscent of currents that permeate through the canonical transient receptor potential (TRPC) channels. Indeed, a few years ago (Kim et al. 2003) reported experiments that 
Synaptic Transmission Mediated by mGluR1 and TRPC3

suggested that the mGluR1-dependent slow EPSC is mediated by TRPC1.

Later studies investigated in more detail TRPC channels in Purkinje cells (Huang et al. 2007; Lein et al. 2007; Hartmann et al. 2008). Although the general notion of an involvement of TRPCs was confirmed, the new experiments did not provide evidence for a specific role of TRPC1. Instead, several lines of evidence pointed to TRPC3 as the postsynaptic channel that mediates the slow EPSC. Thus, the TRPC3 protein was found to be abundant in the somatodendritic compartment of Purkinje cells in the adult mouse brain (Fig. 3A,B) (Hartmann and Konnerth 2008). The number of mRNA copies for TRPC3 is $8-10$ times higher in single Purkinje cells than that of TRPC1 whereas mRNA of the other subunits is present in low amounts. Furthermore, of all TRPC subunits the expression of TRPC3 is most tightly coupled to a developmental time window in which the outgrowth of the dendritic tree of Purkinje cells (Hendelman and Aggerwal 1980), the formation of parallel fiber synapses and the elimination of supernumerary climbing fibers (Scelfo and Strata 2005) take place (Fig. 3C) (Huang et al. 2007). The outstanding role of TRPC3 channels for mGluR1-dependent synaptic transmission in Purkinje cells was unambiguously shown by a recent study that analyzed mGluR1-mediated transmission in specifically designed TRPC-deficient mice (Hartmann et al. 2008) (Figs. 4A-F). The importance of TRPC3 and the mGluR1-dependent slow EPSC for cerebellar function was further emphasized by the behavioral impairments that were observed in TRPC3 null mutant mice. These mice show a movement deficit of their hindpaws that leads to an ataxic wide-based gait and poor performance when they walk on a horizontal ladder or an elevated beam (Hartmann et al. 2008).

The role of TRPC3 for mGluR1-mediated signaling and sensorimotor integration was further corroborated in a study that used mice with a gain-of-function mutation in the Trpc3 gene. A single amino acid exchange in the TRPC3 protein (T635A) results in loss of a phosphorylation site of TRPC3 and altered gating of the channel. Therefore, mGluR1-dependent inward currents are increased and motor coordination is heavily impaired. These so-called moonwalker (Mwk) mice display massive symptoms of ataxia. Remarkably, and in distinct contrast to the TRPC3 knockout mice (Hartmann et al. 2008), increased TRPC3-mediated signaling in Mwk mice is accompanied by a reduced outgrowth of the dendritic arborization of Purkinje cells and even Purkinje cell loss after 4 months of age (Becker et al. 2009). It is remarkable that the absence of TRPC3 is less deleterious for Purkinje cell development than the excess of TRPC3-mediated signaling. The high impact of TRPC3 overexpression may relate to the fact that the developmental increase in TRPC3 expression in Purkinje cells during the first two postnatal weeks (Huang et al. 2007) coincides with the most intensive phase of dendritic growth in these neurons (Hendelman and Aggerwal 1980).

The signaling cascade that links mGluR1 and TRPC3 is not yet fully elucidated. There is evidence that both mGluR1-evoked signal components, the $\mathrm{Ca}^{2+}$ release signal and the slow EPSC, are mediated by $\mathrm{G}_{\mathrm{q}}$ proteins, but subsequently follow divergent pathways (Fig. 5). It has been shown that both $\mathrm{G} \alpha_{\mathrm{q}}$ and $\mathrm{G} \alpha_{11}$ contribute to the generation of the slow EPSC (Hartmann et al. 2004). However, pharmacological manipulations that block the mGluR1dependent $\mathrm{Ca}^{2+}$ release from internal stores do not affect the mGluR1-dependent depolarization (Finch and Augustine 1998; Takechi et al. 1998). Importantly, the two signal components of mGluR1-mediated transmission, the $\mathrm{Ca}^{2+}$ signal and the slow EPSC, may occur independently of each other (Hirono et al. 1998; Takechi et al. 1998; Tempia et al. 1998; Hartmann et al. 2008), as expected from processes that involve distinct intracellular signaling pathways.

The role of PLC $\beta$ in the generation of the mGluR1-dependent slow EPSC is controversial. An involvement of PLC $\beta$ was indicated by the observation that slow EPSC were absent in PLCß4 deficient mutant mice (Sugiyama et al. 1999). However, slow EPSCs seem to be insensitive to the PLC $\beta$ antagonist U73122 (Hirono et al. 1998; Canepari et al. 2001; Glitsch 2010). It has been reported that U73122 abolished 
Hartmann et al.

A TRPC3 in cerebellar Purkinje cells
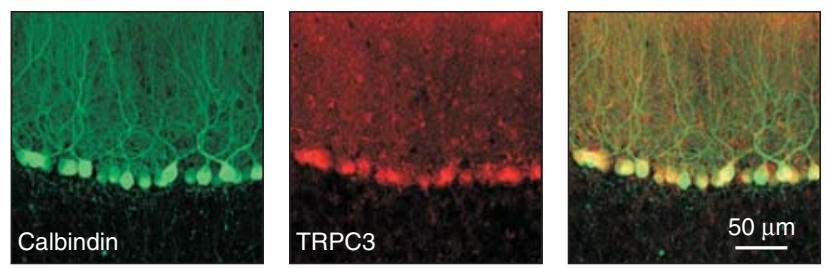

B Quantitative RT-PCR analysis of TRPC subunits

Whole brain

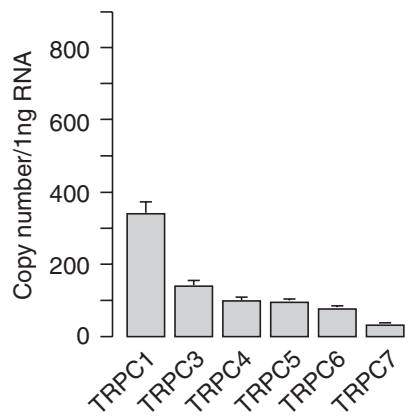

C

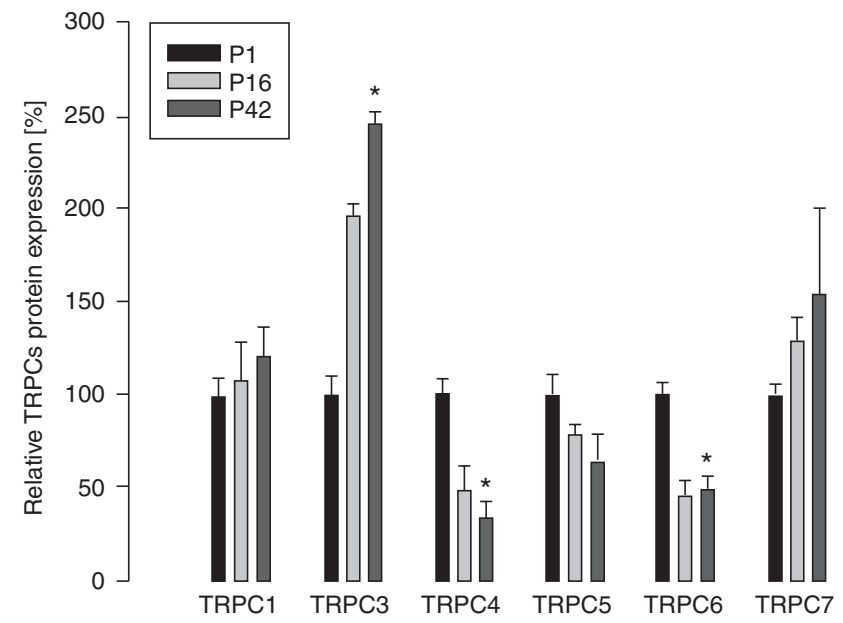

Figure 3. Expression of TRPC channel subunits in the murine brain and single Purkinje cells. (A) A dual-channel confocal scan of an immunohistochemical staining in an acute cerebellar slice. Calbindin D28k immunoreactivity is shown in green (left) and that for TRPC3 in red (middle). Right: Merged images (Hartmann et al. 2008). (B) Copy numbers of TRPC subunit mRNA detected in 1ng total RNA of mouse whole brain (left) and in single Purkinje cells (right). (C) Relative TRPC expression at postnatal days 1 (P1), 16 (P16) and 42 (P42), normalized to average expression value obtained at P1 for a given TRPC subunit. For the quantification, relative Western blot band intensities were analyzed. Data represent averages from three to four independent Western blots. There is a significant increase in TRPC3 expression and a significant decrease in both TRPC4 and TRPC6 expression (unpaired t-tests). (Reprinted with modifications, with permission, from Huang et al. 2007 [Elsevier].) 
Synaptic Transmission Mediated by mGluR1 and TRPC3

A

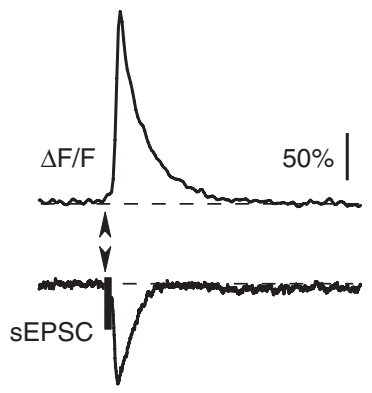

D

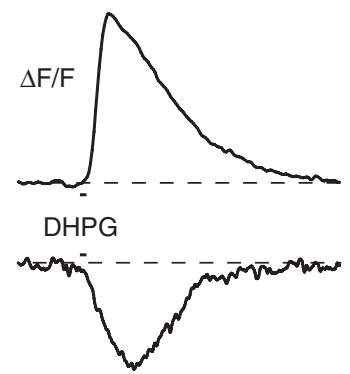

B TRPC3 $^{-/}$

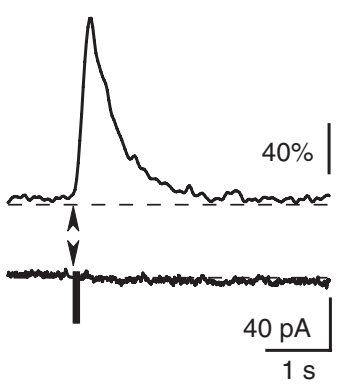

E $\quad$ TRPC3 $^{-1-}$

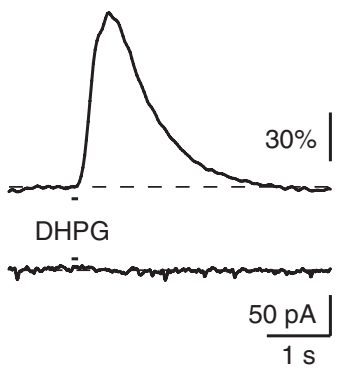

C

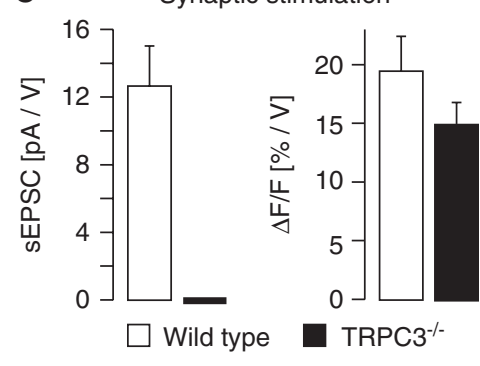

$\mathbf{F}$

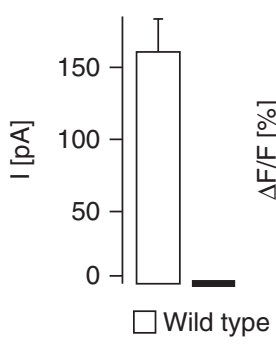

DHPG-application

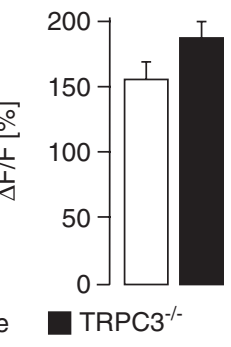

Figure 4. Analysis of TRPC3-deficient mice (Hartmann et al. 2008). (A) Slow EPSC in a wild-type mouse (lower trace) and the corresponding local dendritic $\mathrm{Ca}^{2+}$ response (upper trace). (B) Similar recording in a TRPC $^{-/-}$mouse. (C) Summary graphs for normalized (to stimulation strength) slow EPSCs and $\mathrm{Ca}^{2+}$ transients. (D) DHPG evoked a slow inward current (lower trace) and a local $\mathrm{Ca}^{2+}$ transient (upper trace) in a wildtype mouse. (E) Similar recording in a TRPC $3^{-/}$mouse. (F) Summary of DHPG-evoked current (right) and $\mathrm{Ca}^{2+}(l e f t)$ responses.

the mGluR1-dependent $\mathrm{Ca}^{2+}$ release signal in rat cerebellar slices (Takechi et al. 1998). A possible explanation for these discrepancies may be that the genetic removal of PLC $\beta$ disrupted the tight assembly of the molecular components of the mGluR1-dependent signaling cascade at the postsynaptic density (Nakamura et al. 2004) and that PLC $\beta$ activity is generally not needed for the signal transduction between mGluR1 and TRPC3. A recent study indicated that the activation of mGluR1 initiates two independent signaling pathways downstream of the $\mathrm{G}_{\mathrm{q}}$ proteins: one dependent on the PLC $\beta$ and another one dependent on phospholipase D1 (Fig. 5) (Glitsch 2010). It was shown in that paper that activation of mGluR1 is followed by the translocation of the phospholipase $\mathrm{D}$ to the plasma membrane and that the TRPC3-dependent slow EPSCs in Purkinje cell require the activity of the phospholipase D (PLD). However, PLD most likely does not gate the TRPC3 directly, as suggested by experiments that were performed in a cell line transfected with human TRPC3 (Glitsch 2010). In Purkinje cells, DHPG-evoked inward currents are sensitive to antagonists of the small $G$ proteins of the rho family. From other studies it is known that PLD1 is one of the effectors of rho GTPases (Jenkins and Frohman 2005; Weernink et al. 2007). Thus, it is possible that the activation of TRPC3 through mGluR1 involves a rho GTPase-dependent pathway that depends on PLD1 (Glitsch 2010).

Another subtype of the PLC, namely PLC $\gamma$, which is also found in Purkinje cells (Lein et al. 2007) has been shown to activate TRPC3 in other cell types (van Rossum et al. 2005; Lockwich et al. 2008; Tong et al. 2008) including 
Hartmann et al.
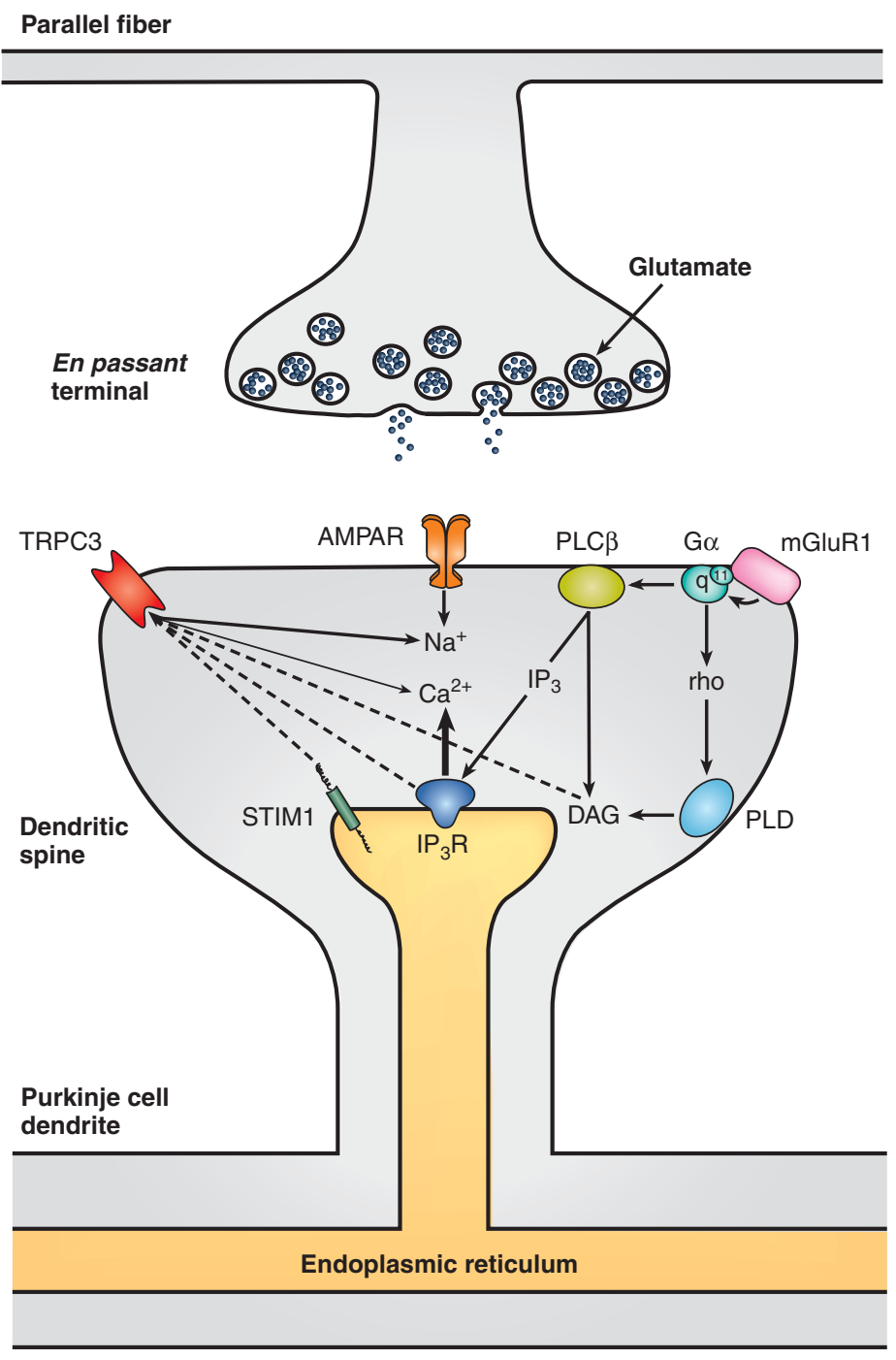

Figure 5. Model of glutamatergic synaptic signaling at parallel fiber-Purkinje cell synapses. Glutamate released from presynaptic terminals binds to AMPA receptors and the mGluR1. Influx of sodium ions through AMPA receptor channels leads to a fast postsynaptic depolarization. The mGluR1 couples predominantly to $G \alpha_{\mathrm{q}}$ but also to $G \alpha_{11}$. This is followed by the activation of the phospholipase $C \beta$ that cleaves phosphatidyl-4,5bisphosphate $\left(\mathrm{PIP}_{2}\right)$ into inositoltrisphosphate $\left(\mathrm{IP}_{3}\right)$ and diacylglycerol (DAG). By binding to its receptor $\left(\mathrm{IP}_{3} \mathrm{R}\right)$ in the endoplasmic reticulum membrane, $\mathrm{IP}_{3}$ releases $\mathrm{Ca}^{2+}$-ions from this intracellular $\mathrm{Ca}^{2+}$-store. TRPC3 channels in Purkinje cells can be activated following stimulation of the PLD and require activity of a small G protein of the Rho family. Possible other candidates for TRPC3 gating are DAG, the stromal interaction molecule 1 (STIM1), the amino terminus of the $\mathrm{IP}_{3} \mathrm{R} 1$ a.o.

neurons ( $\mathrm{Li}$ et al. 1999). However, the internal effector molecule that activates the TRPC3 remains to be determined. It is well established that, when activated, the PLCs, in addition to the soluble factor $\mathrm{IP}_{3}$, produce the lipophilic compound diacylglycerol (DAG) (Weernink et al. 2006). In heterologous expression systems, TRPC3 was shown to be directly regulated by diacylglycerol (DAG) (Fig. 5) (Hofmann et al. 1999; Lemonnier et al. 2008) and by the 
Synaptic Transmission Mediated by mGluR1 and TRPC3

substrate of PLCs, namely phosphatidylinositol-4,5-bisphosphate (Lemonnier et al. 2008). In transfected HEK293 cells, the opening of TRPC3 channels is induced by their binding to the amino-terminal domain of the activated $\mathrm{IP}_{3}$ receptor (Kiselyov et al. 1998; Kiselyov et al. 1999). In the same cell type, there is also an obligatory role of tyrosine kinase Src (Vazquez et al. 2004). In pancreatic acinar cells, the scaffolding protein Homer $1 \mathrm{~b} / \mathrm{c}$ is critical for the regulation of the activity of TRPC3 by the $\mathrm{IP}_{3}$ receptor (Kim et al. 2006). Finally, another interesting component involved in TRPC3 signaling is the stromal interacting molecule I (STIM1) that has an essential role for the $\mathrm{Ca}^{2+}$ homeostasis in the ER in many cell types (Roos et al. 2005; Zhang et al. 2005). STIM1 is a $\mathrm{Ca}^{2+}$ sensor that, following depletion of ER $\mathrm{Ca}^{2+}$ stores, activates a $\mathrm{Ca}^{2+}$ influx through Orai channels in the plasma membrane of nonneuronal cells (Zhang et al. 2005). This so-called store-operated $\mathrm{Ca}^{2+}$ entry (SOCE) ensures the replenishment of $\mathrm{ER} \mathrm{Ca}^{2+}$ stores. Because of their opening downstream of the PLC and their permeability for $\mathrm{Ca}^{2+}$ ions, TRPC channels were proposed to function as store-operated channels (Zhu et al. 1996; Zitt et al. 1997). In HEK293 cells, it has been shown that STIM1 exerts a gating action on TRPC3 by intermolecular electrostatic interaction (Zeng et al. 2008). TRPC3 opens when two positively charged lysine-residues in the carboxyl terminus of STIM1 (684 and 685) get in contact with two negatively charged residues of aspartate (697 and 698) in the intracellular carboxyterminal domain of TRPC3. Purkinje cells express all the factors mentioned above (Lein et al. 2007) and it is important to note that TRPC3 is part of a multi-protein signaling complex that is located postsynaptically and, in addition to the mGluR1, contains also the $\mathrm{IP}_{3} \mathrm{R} 1, \mathrm{PLC \beta} 4$ (Nakamura et al. 2004), Homer proteins ( $\mathrm{Tu}$ et al. 1999; Yuan et al. 2003; Kim et al. 2006) and STIM1 and other TRPC subunits (Yuan et al. 2007). However, whether SOCE requires TRPC channels and whether they are part of the STIM1-Orai-complex is controversially discussed (Liao et al. 2007; Liao et al. 2008; DeHaven et al. 2009).
As most other TRP channels, TRPC3 channels are permeable not only for $\mathrm{Ca}^{2+}$ but also for $\mathrm{Na}^{+}$ions (Zhu et al. 1996; Alexander et al. 2009). It is, therefore, not surprising that TRPC3-mediated slow EPSCs are associated with dendritic $\mathrm{Na}^{+}$transients in Purkinje cells (Knöpfel et al. 2000). These synaptic $\mathrm{Na}^{+}$signals are restricted to dendritic regions that are innervated by the afferent parallel fibers. In addition to $\mathrm{Na}^{+}$transients, mGluR1-dependent slow EPSCs are also associated with dendritic $\mathrm{Ca}^{2+}$ transients that may result in part from $\mathrm{Ca}^{2+}$ entry through TRPC3 channels (Tempia et al. 2001). However, it remains unclear how $\mathrm{Ca}^{2+}$ entry through TRPC3 channels compares to the $\mathrm{Ca}^{2+}$ release signal from internal stores. The answer to this question is important for a better understanding of the induction of LTD, a process known to require a transient elevation in intradendritic $\mathrm{Ca}^{2+}$ concentration (Konnerth et al. 1992).

Another open question concerns the possible molecular partners of TRPC3 channels in Purkinje cells. In view of the fact that Purkinje cells express various TRPCs (Fig. 3), TRPC3 may form heteromers with one or several of those channels (Zagranichnaya et al. 2005). The specific arrangement may determine the relative composition of the ion fluxes (Nilius et al. 2007). Furthermore, the existence of heteromeric complexes of TRPC- and Oraichannels, which may be regulated by STIM1, has been suggested and is controversially discussed at present (Liao et al. 2007; Ong et al. 2007; Cheng et al. 2008; Liao et al. 2008; Zeng et al. 2008; DeHaven et al. 2009). Because all three subtypes of Orai-proteins are expressed in Purkinje cells (Hartmann et al. 2010), such complexes represent possible candidates for the ion channels underlying the mGluR1dependent slow EPSC.

\section{CONCLUSIONS}

In the mammalian central nervous system, mGluR1 is involved in a variety of physiological functions including memory, cognition, the sensation of pain and fear (Gravius et al. 2010). An extensively studied function of the 
Hartmann et al.

mGluR1 is its role in cerebellar sensorimotor integration. The absence of mGluR1 activity in the cerebellar cortex has deleterious consequences for synaptic plasticity (for review, see Rose and Konnerth [2001]) as well as for motor coordination (Aiba et al. 1994; Ichise et al. 2000; Coesmans et al. 2003; Nakao et al. 2007). Even a mild interference with mGluR1dependent signaling cascades invariably leads to ataxia (Hartmann et al. 2004; Hartmann et al. 2008). At parallel fiber-to Purkinje cell synapses, important aspects of mGluR1-dependent signaling became clear in recent years (Fig. 5). Thus, it was found that mGluR1 induces via PLC $\beta$ the release of $\mathrm{Ca}^{2+}$ ions from internal $\mathrm{Ca}^{2+}$ stores in dendrites and spines (Takechi et al. 1998). This process was shown to be important for synaptic plasticity and for motor learning (Miyata et al. 2000). In addition to mediating the release of $\mathrm{Ca}^{2+}$ ions from internal stores, mGluR1 was shown to activate the cation channels TRPC3 (Hartmann et al. 2008). This surprising observation established TRPC3 as a novel postsynaptic channel for glutamatergic synaptic transmission. The gating of TRPC3 downstream of the synaptic activation of mGluR1 has not been entirely clarified, but seems to involve various signaling events, one of which is the rho GTPase-dependent activation of the PLD1 (Glitsch 2010). Other candidate signaling molecules include the $\mathrm{IP}_{3} \mathrm{R}$ itself (Kiselyov et al. 1999), diacylglycerol (Hofmann et al. 1999) and STIM1 (Zeng et al. 2008). A promising experimental strategy for the elucidation of Purkinje cell-specific intracellular signaling events downstream of mGluR1 may involve the functional analysis of cell typeselective mutant mice in vitro and in vivo.

\section{REFERENCES}

Aiba A, Kano M, Chen C, Stanton ME, Fox GD, Herrup K, Zwingman TA, Tonegawa S. 1994. Deficient cerebellar long-term depression and impaired motor learning in mGluR1 mutant mice. Cell 79: 377-388.

Alexander SPH, Mathie A, Peters JA. 2009. Guide to Receptors and Channels (GRAC), 4th Edition. Br J Pharmacol 158: S1-254.

Batchelor AM, Garthwaite J. 1993. Novel synaptic potentials in cerebellar Purkinje cells: probable mediation by metabotropic glutamate receptors. Neuropharmacology 32: $11-20$.

Batchelor AM, Garthwaite J. 1997. Frequency detection and temporally dispersed synaptic signal association through a metabotropic glutamate receptor pathway. Nature 385: 74-77.

Batchelor AM, Madge DJ, Garthwaite J. 1994. Synaptic activation of metabotropic glutamate receptors in the parallel fibre-Purkinje cell pathway in rat cerebellar slices. Neuroscience 63: 911-915.

Becker EB, Oliver PL, Glitsch MD, Banks GT, Achilli F, Hardy A, Nolan PM, Fisher EM, Davies KE. 2009. A point mutation in TRPC3 causes abnormal Purkinje cell development and cerebellar ataxia in moonwalker mice. Proc Natl Acad Sci 106: 6706-6711.

Berstein G, Blank JL, Smrcka AV, Higashijima T, Sternweis PC, Exton JH, Ross EM. 1992. Reconstitution of agonist-stimulated phosphatidylinositol 4,5-bisphosphate hydrolysis using purified $\mathrm{ml}$ muscarinic receptor, Gq/ 11, and phospholipase C-b 1. J Biol Chem 267: 80818088.

Bezprozvanny I, Watras J, Ehrlich BE. 1991. Bell-shaped calcium-response curves of Ins(1,4,5)P3- and calciumgated channels from endoplasmic reticulum of cerebellum. Nature 351: 751-754.

Blank JL, Ross AH, Exton JH. 1991. Purification and characterization of two G-proteins that activate the b1 isozyme of phosphoinositide-specific phospholipase C. Identification as members of the Gq class. J Biol Chem 266: 18206-18216.

Canepari M, Papageorgiou G, Corrie JE, Watkins C, Ogden D. 2001. The conductance underlying the parallel fibre slow EPSP in rat cerebellar Purkinje neurones studied with photolytic release of L-glutamate. J Physiol 533: 765-772.

Cardy TJ, Taylor CW. 1998. A novel role for calmodulin: $\mathrm{Ca}^{2+}$-independent inhibition of type- 1 inositol trisphosphate receptors. Biochem J 334: 447-455.

Chadderton P, Margrie TW, Häusser M. 2004. Integration of quanta in cerebellar granule cells during sensory processing. Nature 428: 856-860.

Cheng KT, Liu X, Ong HL, Ambudkar IS. 2008. Functional requirement for Orail in store-operated TRPC1-STIM1 channels. J Biol Chem 283: 12935-12940.

Coesmans M, Smitt PA, Linden DJ, Shigemoto R, Hirano T, Yamakawa Y, van Alphen AM, Luo C, van der Geest JN, Kros JM, et al. 2003. Mechanisms underlying cerebellar motor deficits due to mGluR1-autoantibodies. Ann Neurol 53: 325-336.

Curtis DR, Phillis JW, Watkins JC. 1959. Chemical excitation of spinal neurones. Nature 183: 611-612.

Daniel H, Levenes C, Fagni L, Conquet F, Bockaert J, Crepel F. 1999. Inositol-1,4,5-trisphosphate-mediated rescue of cerebellar long-term depression in subtype 1 metabotropic glutamate receptor mutant mouse. Neuroscience 92: $1-6$.

DeHaven WI, Jones BF, Petranka JG, Smyth JT, Tomita T, Bird GS, Putney JW Jr. 2009. TRPC channels function independently of STIM1 and Orail. J Physiol 587: 2275-2298. 
Doi T, Kuroda S, Michikawa T, Kawato M. 2005. Inositol 1,4,5-trisphosphate-dependent $\mathrm{Ca}^{2+}$ threshold dynamics detect spike timing in cerebellar Purkinje cells. J Neurosci 25: 950-961.

Dzubay JA, Otis TS. 2002. Climbing fiber activation of metabotropic glutamate receptors on cerebellar Purkinje neurons. Neuron 36: 1159-1167.

Finch EA, Augustine GJ. 1998. Local calcium signalling by inositol-1,4,5-trisphosphate in Purkinje cell dendrites. Nature 396: 753-756.

Fujiwara A, Hirose K, Yamazawa T, Iino M. 2001. Reduced $\mathrm{IP}_{3}$ sensitivity of $\mathrm{IP}_{3}$ receptor in Purkinje neurons. Neuroreport 12: 2647-2651.

Gao W, Dunbar RL, Chen G, Reinert KC, Oberdick J, Ebner TJ. 2003. Optical imaging of long-term depression in the mouse cerebellar cortex in vivo. $J$ Neurosci 23: 1859 1866.

Glitsch MD. 2010. Activation of native TRPC3 cation channels by phospholipase D. FASEB Journal 24: 318-325.

Gravius A, Pietraszek M, Dekundy A, Danysz W. 2010. Metabotropic glutamate receptors as therapeutic targets for cognitive disorders. Curr Top Med Chem 10: 187-206.

Harris KM, Stevens JK. 1988. Dendritic spines of rat cerebellar Purkinje cells: serial electron microscopy with reference to their biophysical characteristics. J Neurosci 8: 4455-4469.

Hartmann J, Konnerth A. 2008. Mechanisms of metabotropic glutamate receptor-mediated synaptic signaling in cerebellar Purkinje cells. Acta Physiol (Oxf) 195: 79-90.

Hartmann J, Blum R, Kovalchuk Y, Adelsberger H, Kuner R, Durand GM, Miyata M, Kano M, Offermanns S, Konnerth A. 2004. Distinct roles of $\mathrm{Ga}_{\mathrm{q}}$ and $\mathrm{Ga}_{11}$ for Purkinje cell signaling and motor behavior. J Neurosci 24: 5119-5130.

Hartmann J, Dragicevic E, Adelsberger H, Henning HA, Sumser M, Abramowitz J, Blum R, Dietrich A, Freichel M, Flockerzi V, et al. 2008. TRPC3 channels are required for synaptic transmission and motor coordination. Neuron 59: 392-398.

Hartmann J, Karl R, Henning AH, Sakimura K, Baba Y, Kurosaki T, Konnerth A. 2010. A role of STIM and Orai proteins in synaptic signaling of cerebellar Purkinje cells. Acta Physiol 198: P-TUE-112.

Hayashi T. 1952. A physiological study of epileptic seizures following cortical stimulation in animals and its application to human clinics. Jpn J Physiol 3: 46-64.

Hendelman WJ, Aggerwal AS. 1980. The Purkinje neuron: I. A Golgi study of its development in the mouse and in culture. J Comp Neurol 193: 1063-1079.

Hirasawa M, Xu X, Trask RB, Maddatu TP, Johnson BA, Naggert JK, Nishina PM, Ikeda A. 2007. Carbonic anhydrase related protein 8 mutation results in aberrant synaptic morphology and excitatory synaptic function in the cerebellum. Mol Cell Neurosci 35: 161-170.

Hirono M, Konishi S, Yoshioka T. 1998. Phospholipase C-independent group I metabotropic glutamate receptor- mediated inward current in mouse Purkinje cells. Biochem Biophys Res Commun 251: 753-758.

Hirono M, Sugiyama T, Kishimoto Y, Sakai I, Miyazawa T, Kishio M, Inoue $\mathrm{H}$, Nakao K, Ikeda M, Kawahara S, et al. 2001. Phospholipase Cb4 and Protein Kinase Ca and/or Protein Kinase CbI Are Involved in the Induction of Long Term Depression in Cerebellar Purkinje Cells. J Biol Chem 276: 45236-45242.

Hirota J, Ando H, Hamada K, Mikoshiba K. 2003. Carbonic anhydrase-related protein is a novel binding protein for inositol 1,4,5-trisphosphate receptor type 1 . Biochem J 372: $435-441$.

Hofmann T, Obukhov AG, Schaefer M, Harteneck C, Gudermann T, Schultz G. 1999. Direct activation of human TRPC6 and TRPC3 channels by diacylglycerol. Nature 397: 259-263.

Houamed KM, Kuijper JL, Gilbert TL, Haldeman BA, O'Hara PJ, Mulvihill ER, Almers W, Hagen FS. 1991. Cloning, expression, and gene structure of a $\mathrm{G}$ proteincoupled glutamate receptor from rat brain. Science 252: $1318-1321$.

Huang WC, Young JS, Glitsch MD. 2007. Changes in TRPC channel expression during postnatal development of cerebellar neurons. Cell Calcium 42: 1-10.

Ichise T, Kano M, Hashimoto K, Yanagihara D, Nakao K, Shigemoto R, Katsuki M, Aiba A. 2000. mGluR1 in cerebellar Purkinje cells essential for long-term depression, synapse elimination, and motor coordination. Science 288: $1832-1835$.

Inoue T, Kato K, Kohda K, Mikoshiba K. 1998. Type 1 inositol 1,4,5-trisphosphate receptor is required for induction of long-term depression in cerebellar Purkinje neurons. J Neurosci 18: 5366-5373.

Isope P, Franconville R, Barbour B, Ascher P. 2004. Repetitive firing of rat cerebellar parallel fibres after a single stimulation. J Physiol 554: 829-839.

Ito M. 2000. Mechanisms of motor learning in the cerebellum. Brain Res 886: 237-245.

Ito M. 2006. Cerebellar circuitry as a neuronal machine. Prog Neurobiol 78: 272-303.

Jenkins J, Frohman M. 2005. Phospholipase D: a lipid centric review. Cell Mol Life Sci 62: 2305-2360.

Jiao Y, Yan J, Zhao Y, Donahue LR, Beamer WG, Li X, Roe BA, Ledoux MS, Gu W. 2005. Carbonic anhydrase-related protein VIII deficiency is associated with a distinctive lifelong gait disorder in waddles mice. Genetics 171: 1239-1246.

Kano M, Hashimoto K, Watanabe M, Kurihara H, Offermanns S, Jiang H, Wu Y, Jun K, Shin HS, Inoue Y, et al. 1998. Phospholipase Cb4 is specifically involved in climbing fiber synapse elimination in the developing cerebellum. Proc Natl Acad Sci 95: 15724-15729.

Kasono K, Hirano T. 1995. Involvement of inositol trisphosphate in cerebellar long-term depression. NeuroReport 6: 569-572.

Kasri NN, Holmes AM, Bultynck G, Parys JB, Bootman MD, Rietdorf K, Missiaen L, McDonald F, De Smedt H, Conway SJ, et al. 2004. Regulation of $\mathrm{Ins}_{3}$ receptor activity by neuronal $\mathrm{Ca}^{2+}$-binding proteins. Embo J 23: 312-321.

Khodakhah K, Armstrong CM. 1997. Induction of longterm depression and rebound potentiation by inositol trisphosphate in cerebellar Purkinje neurons. Proc Natl Acad Sci 94: 14009-14014.

Khodakhah K, Ogden D. 1993. Functional heterogeneity of calcium release by inositol trisphosphate in single 
Hartmann et al.

Purkinje neurones, cultured cerebellar astrocytes, and peripheral tissues. Proc Natl Acad Sci 90: 4976-4980.

Khodakhah K, Ogden D. 1995. Fast activation and inactivation of inositol trisphosphate-evoked $\mathrm{Ca}^{2+}$ release in rat cerebellar Purkinje neurones. J Physiol (Lond) 487: 343-358.

Kim JY, Zeng W, Kiselyov K, Yuan JP, Dehoff MH, Mikoshiba K, Worley PF, Muallem S. 2006. Homer 1 mediates storeand inositol 1,4,5-trisphosphate receptor-dependent translocation and retrieval of TRPC 3 to the plasma membrane. J Biol Chem 281: 32540-32549.

Kim SJ, Kim YS, Yuan JP, Petralia RS, Worley PF, Linden DJ. 2003. Activation of the TRPC1 cation channel by metabotropic glutamate receptor mGluR1. Nature 426: 285-291.

Kiselyov K, Mignery GA, Zhu MX, Muallem S. 1999. The $\mathrm{N}$-terminal domain of the $\mathrm{IP}_{3}$ receptor gates store-operated hTrp3 channels. Mol Cell 4: 423-429.

Kiselyov K, Xu X, Mozhayeva G, Kuo T, Pessah I, Mignery G, Zhu X, Birnbaumer L, Muallem S. 1998. Functional interaction between $\mathrm{InsP}_{3}$ receptors and store-operated Htrp3 channels. Nature 396: 478-482.

Knöpfel T, Anchisi D, Alojado ME, Tempia F, Strata P. 2000. Elevation of intradendritic sodium concentration mediated by synaptic activation of metabotropic glutamate receptors in cerebellar Purkinje cells. Eur J Neurosci 12: 2199-2204.

Knöpfel T, Vranesic I, Staub C, Gahwiler BH. 1991. Climbing Fibre Responses in Olivo-cerebellar Slice Cultures. II Dynamics of Cytosolic Calcium in Purkinje Cells. Eur I Neurosci 3: 343-348.

Konnerth A, Dreessen J, Augustine GJ. 1992. Brief dendritic calcium signals initiate long-lasting synaptic depression in cerebellar Purkinje cells. Proc Natl Acad Sci 89: 7051-7055.

Konnerth A, Llano I, Armstrong CM. 1990. Synaptic currents in cerebellar Purkinje cells. Proc Natl Acad Sci 87: $2662-2665$.

Lein ES, Hawrylycz MJ, Ao N, Ayres M, Bensinger A, Bernard A, Boe AF, Boguski MS, Brockway KS, Byrnes EJ, et al. 2007. Genome-wide atlas of gene expression in the adult mouse brain. Nature 445: 168-176.

Lemonnier L, Trebak M, Putney JW Jr. 2008. Complex regulation of the TRPC 3,6 and 7 channel subfamily by diacylglycerol and phosphatidylinositol-4,5-bisphosphate. Cell Calcium 43: 506-514.

Li HS, Xu XZ, Montell C. 1999. Activation of a TRPC3dependent cation current through the neurotrophin BDNF. Neuron 24: 261-273.

Liao Y, Erxleben C, Abramowitz J, Flockerzi V, Zhu MX, Armstrong DL, Birnbaumer L. 2008. Functional interactions among Orail, TRPCs, and STIM1 suggest a STIMregulated heteromeric Orai/TRPC model for SOCE $/ \mathrm{I}_{\text {crac }}$ channels. Proc Natl Acad Sci 105: 2895-2900.

Liao Y, Erxleben C, Yildirim E, Abramowitz J, Armstrong DL, Birnbaumer L. 2007. Orai proteins interact with TRPC channels and confer responsiveness to store depletion. Proc Natl Acad Sci 104: 4682-4687.

Llano I, Dreessen J, Kano M, Konnerth A. 1991a. Intradendritic release of calcium induced by glutamate in cerebellar Purkinje cells. Neuron 7: 577-583.
Llano I, Marty A, Armstrong CM, Konnerth A. 1991b. Synaptic- and agonist-induced excitatory currents of Purkinje cells in rat cerebellar slices. J Physiol (Lond) 434: 183-213.

Lockwich T, Pant J, Makusky A, Jankowska-Stephens E, Kowalak JA, Markey SP, Ambudkar IS. 2008. Analysis of TRPC3-interacting proteins by tandem mass spectrometry. J Proteome Res 7: 979-989.

Martone ME, Zhang Y, Simpliciano VM, Carragher BO, Ellisman MH. 1993. Three-dimensional visualization of the smooth endoplasmic reticulum in Purkinje cell dendrites. J Neurosci 13: 4636-4646.

Masu M, Tanabe Y, Tsuchida K, Shigemoto R, Nakanishi S. 1991. Sequence and expression of a metabotropic glutamate receptor. Nature 349: 760-765.

Mikoshiba K. 2007. $\mathrm{IP}_{3}$ receptor $/ \mathrm{Ca}^{2+}$ channel: from discovery to new signaling concepts. J Neurochem 102: $1426-1446$.

Miyata M, Finch EA, Khiroug L, Hashimoto K, Hayasaka S, Oda SI, Inouye M, Takagishi Y, Augustine GJ, Kano M. 2000. Local calcium release in dendritic spines required for long-term synaptic depression. Neuron 28: 233-244.

Nakamura F, Ogata K, Shiozaki K, Kameyama K, Ohara K, Haga T, Nukada T. 1991. Identification of two novel GTP-binding protein alpha-subunits that lack apparent ADP-ribosylation sites for pertussis toxin. J Biol Chem 266: $12676-12681$.

Nakamura M, Sato K, Fukaya M, Araishi K, Aiba A, Kano M, Watanabe M. 2004. Signaling complex formation of phospholipase $\mathrm{Cb} 4$ with metabotropic glutamate receptor type 1alpha and 1,4,5-trisphosphate receptor at the perisynapse and endoplasmic reticulum in the mouse brain. Eur J Neurosci 20: 2929-2944.

Nakao H, Nakao K, Kano M, Aiba A. 2007. Metabotropic glutamate receptor subtype- 1 is essential for motor coordination in the adult cerebellum. Neurosci Res 57: 538-543.

Nicoletti F, Iadarola MJ, Wroblewski JT, Costa E. 1986. Excitatory amino acid recognition sites coupled with inositol phospholipid metabolism: developmental changes and interaction with a1-adrenoceptors. Proc Natl Acad Sci 83: 1931-1935.

Nilius B, Owsianik G, Voets T, Peters JA. 2007. Transient receptor potential cation channels in disease. Physiol Rev 87: 165-217.

Nogradi A, Jonsson N, Walker R, Caddy K, Carter N, Kelly C. 1997. Carbonic anhydrase II and carbonic anhydrase-related protein in the cerebellar cortex of normal and lurcher mice. Brain Res Dev Brain Res 98: 91-101.

Nori A, Villa A, Podini P, Witcher DR, Volpe P. 1993. Intracellular $\mathrm{Ca}^{2+}$ stores of rat cerebellum: heterogeneity within and distinction from endoplasmic reticulum. Biochem J 291: 199-204.

Nusser Z, Mulvihill E, Streit P, Somogyi P. 1994. Subsynaptic segregation of metabotropic and ionotropic glutamate receptors as revealed by immunogold localization. Neuroscience 61: 421-427.

Ogden D, Capiod T. 1997. Regulation of $\mathrm{Ca}^{2+}$ release by $\mathrm{InsP}_{3}$ in single guinea pig hepatocytes and rat Purkinje neurons. J Gen Physiol 109: 741-756. 
Ong HL, Cheng KT, Liu X, Bandyopadhyay BC, Paria BC, Soboloff J, Pani B, Gwack Y, Srikanth S, Singh BB, et al. 2007. Dynamic assembly of TRPC1/STIM1/Orail ternary complex is involved in store operated calcium influx: Evidence for similarities in SOC and CRAC channel components. J Biol Chem 282: 9105-9116.

Ozawa S, Kamiya H, Tsuzuki K. 1998. Glutamate receptors in the mammalian central nervous system. Prog Neurobiol 54: 581-618.

Patel S, Morris SA, Adkins CE, O’Beirne G, Taylor CW. 1997. $\mathrm{Ca}^{2+}$-independent inhibition of inositol trisphosphate receptors by calmodulin: redistribution of calmodulin as a possible means of regulating $\mathrm{Ca}^{2+}$ mobilization. Proc Natl Acad Sci 94: 11627-11632.

Patterson RL, Boehning D, Snyder SH. 2004. Inositol 1,4,5-trisphosphate receptors as signal integrators. Annu Rev Biochem 73: 437-465.

Rebecchi MJ, Pentyala SN. 2000. Structure, function, and control of phosphoinositide-specific phospholipase C. Physiol Rev 80: 1291-1335.

Roos J, DiGregorio PJ, Yeromin AV, Ohlsen K, Lioudyno M, Zhang S, Safrina O, Kozak JA, Wagner SL, Cahalan MD, et al. 2005. STIM1, an essential and conserved component of store-operated $\mathrm{Ca}^{2+}$ channel function. J Cell Biol 169: 435-444.

Rose CR, Konnerth A. 2001. Stores not just for storage. intracellular calcium release and synaptic plasticity. $\mathrm{Neu}$ ron 31: 519-522.

Roustan P, Abitbol M, Menini C, Ribeaudeau F, Gerard M, Vekemans M, Mallet J, Dufier JL. 1995. The rat phospholipase $\mathrm{Cb} 4$ gene is expressed at high abundance in cerebellar Purkinje cells. Neuroreport 6: 1837-1841.

Scelfo B, Strata P. 2005. Correlation between multiple climbing fibre regression and parallel fibre response development in the postnatal mouse cerebellum. Eur J Neurosci 21: 971-978.

Sharp AH, Nucifora FC Jr, Blondel O, Sheppard CA, Zhang C, Snyder SH, Russell JT, Ryugo DK, Ross CA. 1999. Differential cellular expression of isoforms of inositol 1,4,5-triphosphate receptors in neurons and glia in brain. J Comp Neurol 406: 207-220.

Shigemoto R, Nakanishi S, Mizuno N. 1992. Distribution of the mRNA for a metabotropic glutamate receptor (mGluR1) in the central nervous system: an in situ hybridization study in adult and developing rat. J Comp Neurol 322: 121-135.

Shin JH, Linden DJ. 2005. An NMDA receptor/nitric oxide cascade is involved in cerebellar LTD but is not localized to the parallel fiber terminal. J Neurophysiol 94: 4281-4289.

Sladeczek F, Pin JP, Recasens M, Bockaert J, Weiss S. 1985. Glutamate stimulates inositol phosphate formation in striatal neurones. Nature 317: 717-719.

Sugiyama H, Ito I, Hirono C. 1987. A new type of glutamate receptor linked to inositol phospholipid metabolism. Nature 325: 531-533.

Sugiyama T, Hirono M, Suzuki K, Nakamura Y, Aiba A, Nakamura K, Nakao K, Katsuki M, Yoshioka T. 1999. Localization of phospholipase $\mathrm{Cb}$ isozymes in the mouse cerebellum. Biochem Biophys Res Commun 265: 473-478.
Takechi H, Eilers J, Konnerth A. 1998. A new class of synaptic response involving calcium release in dendritic spines. Nature 396: 757-760.

Takei K, Stukenbrok H, Metcalf A, Mignery GA, Südhof TC, Volpe P, De Camilli P. 1992. $\mathrm{Ca}^{2+}$ stores in Purkinje neurons: endoplasmic reticulum subcompartments demonstrated by the heterogeneous distribution of the $\mathrm{InsP}_{3}$ receptor, $\mathrm{Ca}^{2+}$-ATPase, and calsequestrin. J Neurosci 12: 489-505.

Tanaka O, Kondo H. 1994. Localization of mRNAs for three novel members (b 3, b 4 and g 2) of phospholipase C family in mature rat brain. Neurosci Lett 182: 17-20.

Tanaka J, Nakagawa S, Kushiya E, Yamasaki M, Fukaya M, Iwanaga T, Simon MI, Sakimura K, Kano M, Watanabe M. 2000. Gq protein alpha subunits $\mathrm{Ga}_{\mathrm{q}}$ and $\mathrm{Ga}_{11}$ are localized at postsynaptic extra-junctional membrane of cerebellar Purkinje cells and hippocampal pyramidal cells. Eur J Neurosci 12: 781-792.

Tempia F, Alojado ME, Strata P, Knöpfel T. 2001. Characterization of the mGluR(1)-mediated electrical and calcium signaling in Purkinje cells of mouse cerebellar slices. $J$ Neurophysiol 86: 1389-1397.

Tempia F, Miniaci MC, Anchisi D, Strata P. 1998. Postsynaptic current mediated by metabotropic glutamate receptors in cerebellar Purkinje cells. J Neurophysiol 80: $520-528$.

Terasaki M, Slater NT, Fein A, Schmidek A, Reese TS. 1994. Continuous network of endoplasmic reticulum in cerebellar Purkinje neurons. Proc Natl Acad Sci 91: 75107514.

Tong Q, Hirschler-Laszkiewicz I, Zhang W, Conrad K, Neagley DW, Barber DL, Cheung JY, Miller BA. 2008. TRPC3 is the erythropoietin-regulated calcium channel in human erythroid cells. J Biol Chem 283: 10385-10395.

Tu JC, Xiao B, Naisbitt S, Yuan JP, Petralia RS, Brakeman P, Doan A, Aakalu VK, Lanahan AA, Sheng M, et al. 1999. Coupling of mGluR/Homer and PSD-95 complexes by the Shank family of postsynaptic density proteins. Neuron 23: 583-592.

van Rossum DB, Patterson RL, Sharma S, Barrow RK, Kornberg M, Gill DL, Snyder SH. 2005. Phospholipase Cgammal controls surface expression of TRPC 3 through an intermolecular PH domain. Nature 434: 99-104.

Vazquez G, Wedel BJ, Kawasaki BT, Bird GS, Putney JW Jr. 2004. Obligatory role of Src kinase in the signaling mechanism for TRPC3 cation channels. J Biol Chem 279: 40521-40528.

Verkhratsky A. 2005. Physiology and pathophysiology of the calcium store in the endoplasmic reticulum of neurons. Physiol Rev 85: 201-279.

Villa A, Podini P, Clegg DO, Pozzan T, Meldolesi J. 1991. Intracellular $\mathrm{Ca}^{2+}$ stores in chicken Purkinje neurons: differential distribution of the low affinity-high capacity $\mathrm{Ca}^{2+}$ binding protein, calsequestrin, of $\mathrm{Ca}^{2+}$ ATPase and of the ER lumenal protein, Bip. J Cell Biol 113: 779-791.

Villa A, Sharp AH, Racchetti G, Podini P, Bole DG, Dunn WA, Pozzan T, Snyder SH, Meldolesi J. 1992. The endoplasmic reticulum of Purkinje neuron body and dendrites: molecular identity and specializations for $\mathrm{Ca}^{2+}$ transport. Neuroscience 49: 467-477. 
Hartmann et al.

Wang SS, Denk W, Hausser M. 2000. Coincidence detection in single dendritic spines mediated by calcium release. Nat Neurosci 3: 1266-1273.

Watanabe M, Nakamura M, Sato K, Kano M, Simon MI, Inoue Y. 1998. Patterns of expression for the mRNA corresponding to the four isoforms of phospholipase $\mathrm{Cb}$ in mouse brain. Eur J Neurosci 10: 2016-2025.

Watras J, Orlando R, Moraru II. 2000. An endogenous sulfated inhibitor of neuronal inositol trisphosphate receptors. Biochemistry 39: 3452-3460.

Weernink O, Lopéz de Jesus PA, Schmidt M. 2007. Phospholipase D signaling: orchestration by PIP2 and small GTPases. Naunyn Schmiedeberg Arch Pharmacol 374: 399-411.

Weernink PAO, Han L, Jakobs KH, Schmidt M. 2006. Dynamic phospholipid signaling by $G$ protein-coupled receptors. Biochimica et Biophysica acta 1768: 888-900.

Wilkie TM, Scherle PA, Strathmann MP, Slepak VZ, Simon MI. 1991. Characterization of G-protein a subunits in the $\mathrm{G}_{\mathrm{q}}$ class: expression in murine tissues and in stromal and hematopoietic cell lines. Proc Natl Acad Sci 88: 10049_ 10053.

Yuan JP, Kiselyov K, Shin DM, Chen J, Shcheynikov N, Kang SH, Dehoff MH, Schwarz MK, Seeburg PH, Muallem S, et al. 2003. Homer binds TRPC family channels and is required for gating of TRPC1 by $\mathrm{IP}_{3}$ receptors. Cell 114: 777-789.
Yuan JP, Zeng W, Huang GN, Worley PF, Muallem S. 2007. STIM1 heteromultimerizes TRPC channels to determine their function as store-operated channels. Nat Cell Biol 9: 636-645.

Zagranichnaya TK, Wu X, Villereal ML. 2005. Endogenous TRPC1, TRPC3, and TRPC7 proteins combine to form native store-operated channels in HEK-293 cells. J Biol Chem 280: 29559-29569.

Zeng W, Yuan JP, Kim MS, Choi YJ, Huang GN, Worley PF, Muallem S. 2008. STIM1 Gates TRPC Channels, but Not Orai1, by Electrostatic Interaction. Mol Cell 32: 439-448.

Zhang SL, Yu Y, Roos J, Kozak JA, Deerinck TJ, Ellisman MH, Stauderman KA, Cahalan MD. 2005. STIM1 is a $\mathrm{Ca}^{2+}$ sensor that activates CRAC channels and migrates from the $\mathrm{Ca}^{2+}$ store to the plasma membrane. Nature 437: 902-905.

Zhu X, Jiang M, Peyton M, Boulay G, Hurst R, Stefani E, Birnbaumer L. 1996. trp, a novel mammalian gene family essential for agonist-activated capacitative $\mathrm{Ca}^{2+}$ entry. Cell 85: 661-671.

Zitt C, Obukhov AG, Strubing C, Zobel A, Kalkbrenner F, Luckhoff A, Schultz G. 1997. Expression of TRPC3 in Chinese hamster ovary cells results in calcium-activated cation currents not related to store depletion. J Cell Biol 138: $1333-1341$. 


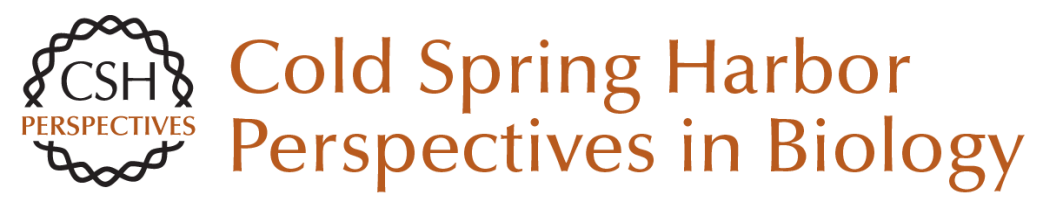

\title{
mGluR1/TRPC3-mediated Synaptic Transmission and Calcium Signaling in Mammalian Central Neurons
}

\author{
Jana Hartmann, Horst A. Henning and Arthur Konnerth
}

Cold Spring Harb Perspect Biol 2011; doi: 10.1101/cshperspect.a006726 originally published online January 26, 2011

\section{Subject Collection Calcium Signaling}

The Endoplasmic Reticulum-Plasma Membrane Junction: A Hub for Agonist Regulation of $\mathrm{Ca}^{2+}$ Entry

Hwei Ling Ong and Indu Suresh Ambudkar

Calcium-Handling Defects and Neurodegenerative

Disease

Sean Schrank, Nikki Barrington and Grace E. Stutzmann

Lysosomal $\mathrm{Ca}^{2+}$ Homeostasis and Signaling in Health and Disease

Emyr Lloyd-Evans and Helen Waller-Evans

$\mathrm{Ca}^{2+}$ Signaling in Exocrine Cells

Malini Ahuja, Woo Young Chung, Wei-Yin Lin, et al.

Functional Consequences of Calcium-Dependent Synapse-to-Nucleus Communication: Focus on Transcription-Dependent Metabolic Plasticity Anna M. Hagenston, Hilmar Bading and Carlos Bas-Orth

Identifying New Substrates and Functions for an Old Enzyme: Calcineurin

Jagoree Roy and Martha S. Cyert

Fundamentals of Cellular Calcium Signaling: A

Primer

Martin D. Bootman and Geert Bultynck
Primary Active $\mathrm{Ca}^{2+}$ Transport Systems in Health and Disease

Jialin Chen, Aljona Sitsel, Veronick Benoy, et al.

Signaling through $\mathrm{Ca}^{2+}$ Microdomains from

Store-Operated CRAC Channels

Pradeep Barak and Anant B. Parekh

Structural Insights into the Regulation of $\mathrm{Ca}^{2+}$

/Calmodulin-Dependent Protein Kinase II (CaMKII) Moitrayee Bhattacharyya, Deepti Karandur and John Kuriyan

Store-Operated Calcium Channels: From Function

to Structure and Back Again Richard S. Lewis

Bcl-2-Protein Family as Modulators of $\mathrm{IP}_{3}$

Receptors and Other Organellar $\mathrm{Ca} 2+$ Channels Hristina Ivanova, Tim Vervliet, Giovanni Monaco, et al.

Calcium Signaling in Cardiomyocyte Function Guillaume Gilbert, Kateryna Demydenko, Eef Dries, et al.

Cytosolic $\mathrm{Ca}^{2+}$ Buffers Are Inherently $\mathrm{Ca}^{2+}$ Signal Modulators Beat Schwaller

For additional articles in this collection, see http://cshperspectives.cshlp.org/cgi/collection/

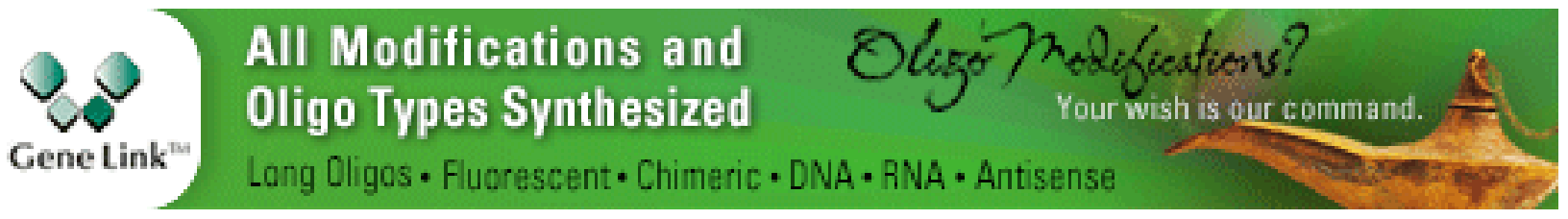


Role of Two-Pore Channels in Embryonic Development and Cellular Differentiation Sarah E. Webb, Jeffrey J. Kelu and Andrew L. Miller

\section{Organellar Calcium Handling in the Cellular \\ Reticular Network}

Wen-An Wang, Luis B. Agellon and Marek Michalak

For additional articles in this collection, see http://cshperspectives.cshlp.org/cgi/collection/

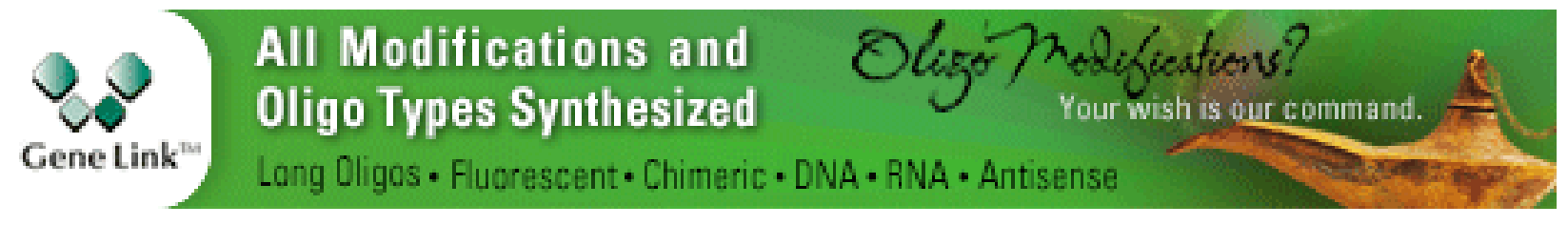

Copyright @ 2011 Cold Spring Harbor Laboratory Press; all rights reserved 